PEREIRA, AS; SILVA, GO; BERTONCINI, O; CASTRO, CM; BORTOLETTO, AC; HIRANO, E; AZEVEDO, FQ; LIMA, MF; GOMES, CB; DUTRA, LF; SUINAGA, FA; CARVALHO, ADF; MELO, PE; LOPES, CA; REISSER JUNIOR, C; PINHEIRO, JB; MEDEIROS CAB; KROLOW, ACR; CASTRO, LAS; NAZARENO, NRX. 2018. BRS F63 (Camila): A fresh market potato cultivar, with high yield potential and resistance to virus Y. Horticultura Brasileira 36: 136-140. DOI - http://dx.doi.org/10.1590/S0102-053620180123

\title{
BRS F63 (Camila): A fresh market potato cultivar, with high yield potential and resistance to virus $Y$
}

\author{
Arione S Pereira ${ }^{1}$; Giovani O Silva²; Odone Bertoncini ${ }^{3}$; Caroline M Castro ${ }^{1}$; Antonio C Bortoletto ${ }^{3}$; Elcio Hirano ${ }^{3}$; \\ Fernanda Q Azevedo'; Mirtes F Lima²; Cesar B Gomes ${ }^{1}$; Leonardo F Dutra ${ }^{1}$; Fabio A Suinaga²; Agnaldo DF \\ Carvalho $^{2}$; Paulo E Melo ; Carlos A Lopes²; Carlos Reisser Junior'; Jadir B Pinheiro²; Carlos AB Medeiros ${ }^{1}$; \\ Ana CR Krolow ${ }^{1}$; Luis AS Castro ${ }^{1}$; Nilceu RX de Nazareno ${ }^{5}$
}

${ }^{1}$ Embrapa Clima Temperado, Pelotas-RS, Brazil; arione.pereira@embrapa.br; ${ }^{2}$ Embrapa Hortaliças, Brasília-DF, Brazil; ${ }^{3}$ Embrapa Produtos e Mercado, Canoinhas-SC, Brazil; ${ }^{4}$ Embrapa Secretaria de Relações Internacionais, Brasília-DF, Brazil; ${ }^{5}$ Iapar, Curitiba-PR, Brazil

\begin{abstract}
Camila potato, registered and protected as BRS F63, is a cultivar for the fresh market, with oval tubers of attractive appearance, having shallow eyes, yellow and smooth skin, and light yellow flesh. It presents medium specific gravity (dry matter), which allows greater culinary versatility than 'Agata'. Cooked tubers have a firm texture and distinctive flavor, with potential for use even in gourmet kitchen, for preparing salads and other similar dishes. The vegetative growth cycle and dormancy are medium. It presents high productive potential, with high percentage of marketable tubers. It is moderately resistant to greening. Concerning physiological disorders in the tubers, 'BRS F63' (Camila) is similar to 'Agata' and 'Asterix' in crops of subtropical ecosystem, but the incidence increases in plantations outside the Winter crop in tropical ecosystem. It is moderately susceptible to Phytophthora infestans and Alternaria spp., which can be managed effectively with fungicides. It has extreme resistance to virus $Y\left(R y_{s t o}\right)$, which reduces the loss of seed quality, allowing more generations of multiplication.
\end{abstract}

Keywords: Solanum tuberosum, genetic breeding, PVY, variety.

\section{RESUMO}

BRS F63 (Camila): Cultivar de batata para consumo, com alto potencial produtivo e resistência ao vírus $\mathrm{Y}$

Batata Camila, registrada e protegida como BRS F63, é uma cultivar destinada ao mercado de consumo, com tubérculos ovalados de aparência atrativa, tendo gemas superficiais, película amarela e lisa, e polpa amarelo-clara. Apresenta peso específico médio (massa seca), que permite maior versatilidade na culinária do que a cultivar Agata. Na cocção apresenta textura firme e sabor característico, com potencial para uso inclusive em cozinha gourmet, na preparação de salada e outros pratos afins. O ciclo de desenvolvimento vegetativo e a dormência são médios. Apresenta alto potencial produtivo, com elevada percentagem de tubérculos comerciais. É moderadamente resistente ao esverdeamento. Quanto a desordens fisiológicas nos tubérculos, 'BRS F63' (Camila) apresenta incidência similar à 'Agata' e 'Asterix' nas safras do ecossistema subtropical, porém a incidência aumenta em plantios fora da safra de inverno no ecossistema tropical. É moderadamente suscetível a Phytophthora infestans e a Alternaria spp., que podem ser manejadas eficazmente com fungicidas. Apresenta resistência extrema ao vírus $\mathrm{Y}\left(R y_{s t o}\right)$, que reduz a perda de qualidade da semente, permitindo maior número de gerações de multiplicação.

Palavras-chave: Solanum tuberosum, melhoramento genético, PVY, variedade.

\section{Received on May 30, 2017; accepted on January 11, 2018}

$\mathrm{C}$ amila, registered and protected as BRS F63, is a potato cultivar for fresh market being selected on basis of tuber appearance, yield and specific gravity, released in 2015. 'BRS F63' (Camila) was developed by the Embrapa Potato Breeding Program, constituted by the Embrapa Temperate Agriculture, Pelotas-RS, Embrapa Vegetable Crops, Brasília-DF, and Embrapa Products and Market, Office of Canoinhas-SC.

F63-01-06 was originated from a cross between two clones selected by Embrapa, C1750-15-95 (mother) and C1883-22-97 (father) (Figure 1), made in a greenhouse of the Embrapa Temperate Agriculture, in 2004. C1750$15-95$ is a clone selected from the cross between the clone C1485-16-87 and the North American cultivar Atlantic (The Potato Association of America, 2016). The clone C1485-16-87 was derived from the cross between two clones selected by Embrapa, 2CRI1149-1-78 and A876-5-79. The first was obtained of the cross between the Dutch cultivar
Recent and the clone CI1086-22-75, while the second was selected from self-fertilization of the Brazilian old cultivar Palma. Except 'C1750-1595', all other clones included in the pedigree of 'BRS F63' (Camila) were developed by the breeder Delorge Mota da Costa. The clone C1883-22-97 was developed from a population received from the International Potato Center (CIP), obtained from the cross between the clones ND860-2 and XY-14. The clone ND860-2 was developed by the 
North Dakota State University, USA (Ehlenfeldt et al., 1990). The clone XY14 was developed by CIP.

True potato seeds of the hybrid population that originated the clone F63-01-06 were sown in greenhouse of the Embrapa Temperate Agriculture, in the Spring of 2005, producing seedling tubers to plant the first field generation. The selection process comprised four generations conducted in the Spring seasons of 2006, 2007, 2008 and 2009, in fields of collaborator growers of Embrapa Products and Market, Office of Canoinhas (Pereira et al., 2016). In 2008 and 2009, the selected clones were submitted to clonal cleaning in the tissue culture laboratory and production of genetic seeds in the hydroponic system of Embrapa Temperate Agriculture; and production of genetic basic seeds in fields of collaborator growers of Embrapa Products and Market, Office of Canoinhas.

During the Fall season of 2010, Fall and Spring seasons of 2011, and Fall season of 2012 in Pelotas, and Canoinhas, and of the "dry" season of 2010 in Londrina-PR, the clone 'F6301-06' was included in comparative trials, to evaluate yield potential and yield stability. Simultaneously, the clone was also evaluated for main common diseases in Brazil, by the Embrapa Vegetable Crops and Embrapa Temperate Agriculture.

Finally, in the Spring season of 2012, Fall season of 2013, and Spring season of 2013, the clone 'F63-01-06' was tested in the Value for Cultivation and Use (VCU) trials, in Canoinhas and Pelotas, using Agata and Asterix as tester cultivars. In these trials, morphological characterization was done, with 'F6301-06' demonstrating phenotypic and genetic distinctness, homogeneity and stability. Concurrently with the VCU trials, 'F63-01-06' was agronomically and commercially validated by growers from different regions of the country, and initiated seed multiplication.

Based on tuber appearance, yield potential, specific gravity and resistance to PVY, and the validation results, the clone 'F63-01-06' was released as cultivar BRS F63 (Camila).

\section{VARIETAL DESCRIPTION}

Description of plant and tubers of 'BRS F63' (Camila) was obtained from evaluation fields carried out in Pelotas.

Plants: moderately vigorous, with semi-erect growth habit, medium height, and medium vegetative cycle.

Leaves: moderately open, green color of medium intensity and without pigmentation on the midribs (Figure 2A).

Leaflets: large size, non-coalescent, without waves in the margins and with medium frequency of secondary leaflets.

Flowers: very low frequency of inflorescences, with medium pedicels and anthocyanin pigmentation absent (Figure 2B).

Corolla: white.

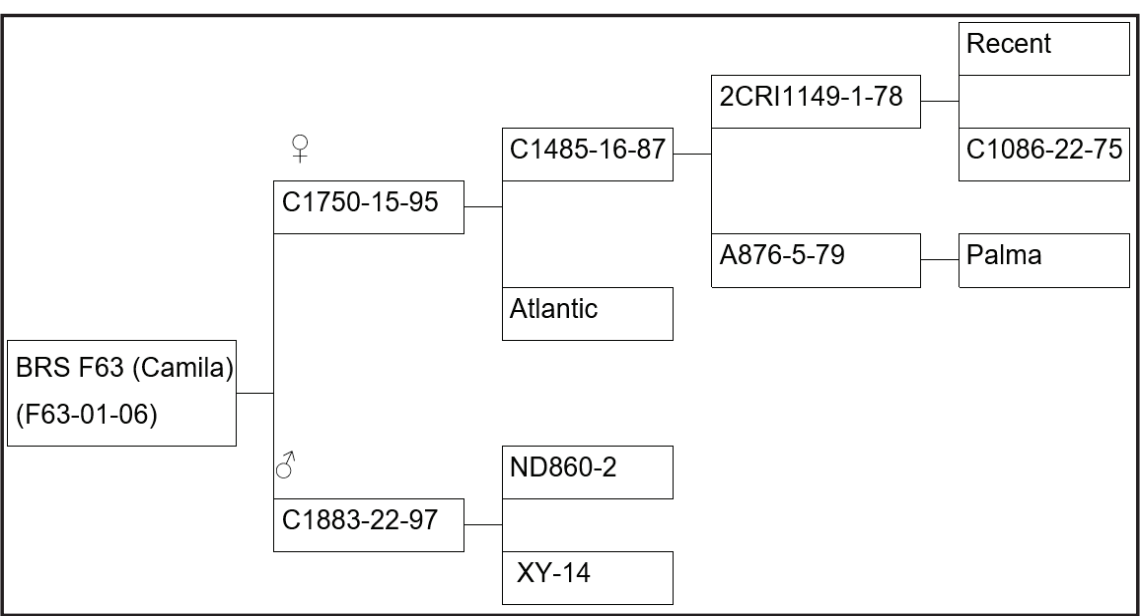

Figure 1. Pedigree of cultivar BRS F63 (Camila). Pelotas, Embrapa Temperate Agriculture, 2017.
Fruits: absent.

Tubers: oval shape, yellow and smooth skin, moderately resistant to post-harvest greening, shallow eyes, light yellow flesh, and medium dormancy (Figure 2C).

Sprouts: wide cylindrical shape and closed apex, root primordia of medium intensity (Figure 2D).

\section{AGRONOMIC PERFORMANCE}

In six trials performed in Canoinhas, Pelotas, and Brasília, 'BRS F63' (Camila) showed marketable tuber yield (transversal diameter greater than 45 $\mathrm{mm})$ significantly $(\mathrm{p}<0.05)$ greater than 'Agata' and 'Asterix' in four trials, and did not differ in two of them, including the only Winter season trial in Brasília (Table 1).

The total tuber yield of 'BRS F63' (Camila) did not differ from 'Agata' in four trials, being significantly superior in one, and inferior in one Spring season trial in Canoinhas, and did not differ from 'Asterix' in none of the trials.

The marketable yield and the average tuber weight of 'BRS F63' (Camila) were superior or equal to both check cultivars.

In the validation tests conducted by growers of diverse regions of the country, the superiority of 'BRS F63' (Camila) was proven. But in plantings out of the Winter season in the tropical ecosystem, a significant incidence of physiological disorders in the tubers was observed, suggesting that planting in this ecosystem has to be restricted to the Winter season.

The average tuber weight of 'BRS F63' (Camila) was higher than of the check cultivars in the majority of trials (Table 1).

\section{QUALITY \\ CHARACTERISTICS AND \\ USAGE}

Specific gravity - The specific 


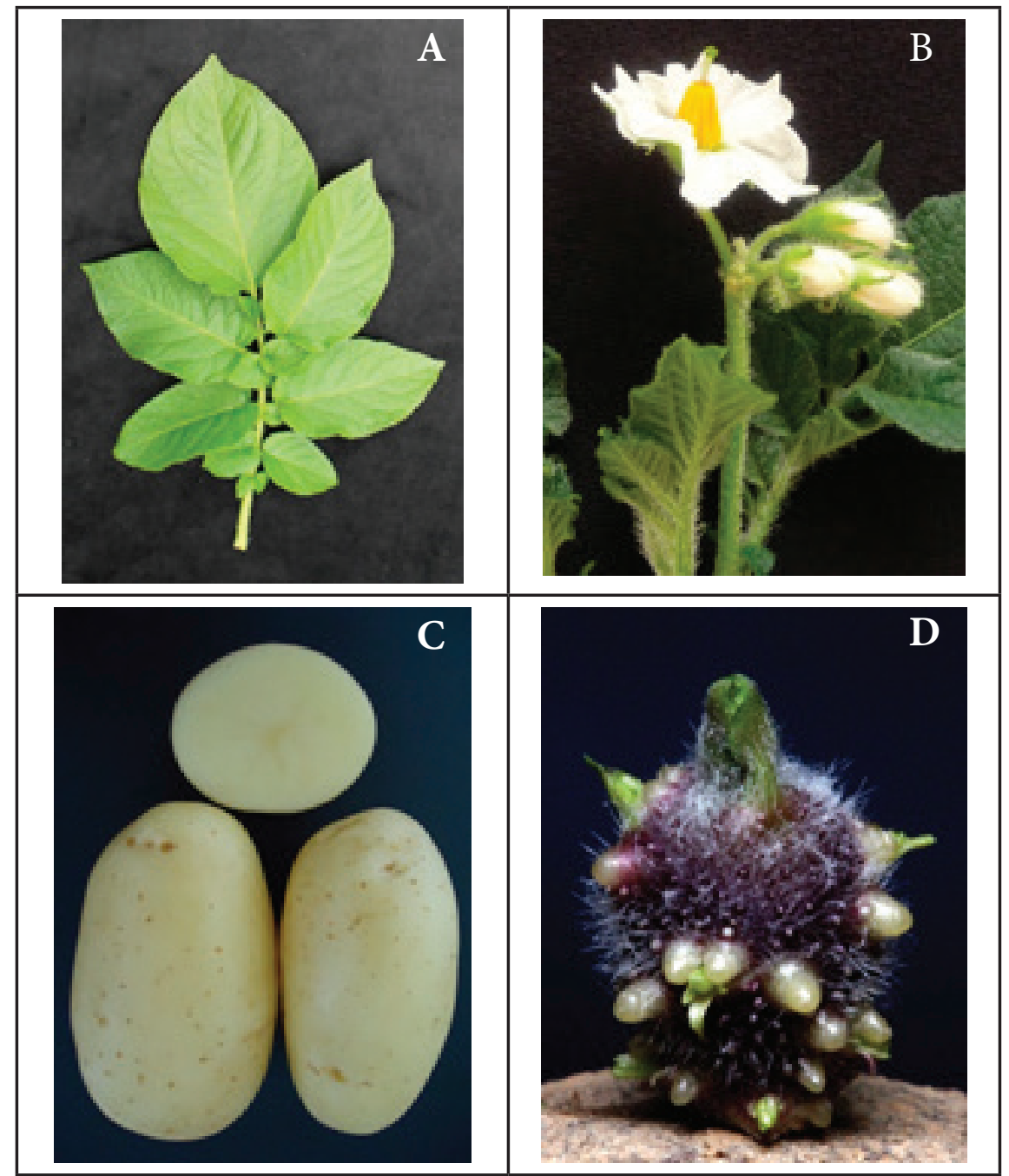

Figure 2. Morphological characteristics of the cultivar BRS F63 (Camila); A) compound leaf, B) inflorescence, C) tubers, and D) sprout. Pelotas, Embrapa Temperate Agriculture, 2017.

gravity of 'BRS F63' tubers (1.073 to 1.078) was significantly higher than of 'Agata' (1.054 to 1.072), and lower than of 'Asterix' (1.079 to 1.088 ), in four and three of five trials, respectively (Table 1).

Tuber disorders - The incidence of physiological disorders from 'BRS F63' (Camila) was similar to the check cultivars, with some variation in the disorder type. In relation to external disorders (secondary growth and growth cracks), 'BRS F63' (Camila) (1.0\% and $0.7 \%)$ was similar to 'Agata' $(1.2 \%$ and $0.7 \%$ ) and with a lower incidence than 'Asterix' (3.8\% and 1.0\%) in relation to secondary growth. Regarding the internal disorders (hollow heart and brown spot), 'BRS F63' (Camila) had a higher incidence of hollow heart (3.6\%) than 'Agata' (1.9\%) and 'Asterix'
$(0.5 \%)$, but showed no brown spot, while 'Agata' and 'Asterix' had 1.4\% and $0.5 \%$, respectively. The occurrence tubers was not consistent through the seasons, occurring in three of the six trials.

In the agronomic validation tests, excluding the Winter season in the tropical ecosystem, 'BRS F63' (Camila) presented a high incidence of both external and internal disorders.

Culinary quality - The medium specific gravity (dry matter) of 'BRS F63' (Camila) allows greater culinary versatility than 'Agata', presenting firm texture after cooking and characteristic flavor, with potential for use even in gourmet cooking, in the preparation of salad and other related dishes. of hollow heart on 'BRS F63' (Camila)
Resistance to greening - Samples of ten freshly harvested tubers were washed and exposed to natural light during nine days. The external intensity of greening observed at five, seven and nine days of light exposure using a ninepoint scale $(1=$ absent $/$ very weak, $3=$ weak, $5=$ medium, $7=$ strong and $9=$ very strong) was weak, strong and very strong, respectively, in both 'BRS F63' (Camila) and 'Agata'.

\section{DISEASE REACTION}

Regarding to late blight (Phytophthora infestans), 'BRS F63' (Camila) showed moderate resistance in field tests under conditions of artificial inoculation. Field observations indicate also moderate resistance to early blight (Alternaria spp.). 'BRS F63' (Camila) presented extreme resistance in field tests to mosaic caused by Potato virus $Y$ (PVY), considering symptom expressions in plants and utilization of specific antiserum, in DAS-ELISA test (double antibody sandwich - Enzyme linked immunosorbent assay) (Clark \& Adams, 1977). The M45 molecular marker test (Brigneti et al., 1997), which detects the presence of the $R y_{\text {sto }}$ gene, that confers extreme resistance to PVY, was positive. In relation to other diseases, so far there is no information about the behavior of this cultivar. In tests of reaction to root-knot nematode (Meloidogyne spp.) in field with high natural infection, in Brasília, the 'BRS F63' (Camila) showed a reproduction factor (RF) less than 1 (resistant), it behaved as susceptible to $M$. javanica at greenhouse conditions (Schaefer $e t$ al., 2017).

\section{CROP MANAGEMENT}

The management practices of 'BRS F63' (Camila) are, in general, common to those used for other medium maturity cultivars. Altough there is a limited number of studies and management observations, 'BRS F63' (Camila) has shown good resistance to the herbicide metribuzin in applications according to the product label.

Considering that this cultivar shows 
Table 1. Mean yield traits and specific gravity of BRS F63 (Camila) potato cultivar and checks in crop seasons of 2012 and 2013 , in Canoinhas-SC, Pelotas-RS, and Brasília-DF. Pelotas, Embrapa Temperate Agriculture, 2017.

\begin{tabular}{|c|c|c|c|c|c|c|}
\hline \multirow{2}{*}{ Local (season) } & \multirow{2}{*}{ Cultivar } & \multicolumn{2}{|c|}{ Yield (t ha $\left.{ }^{-1}\right)$} & \multirow{2}{*}{$\begin{array}{l}\text { Marketable } \\
\text { yield (\%) }\end{array}$} & \multirow{2}{*}{$\begin{array}{l}\text { Average tuber } \\
\text { weight (g) }\end{array}$} & \multirow{2}{*}{$\begin{array}{l}\text { Specific } \\
\text { gravity }\end{array}$} \\
\hline & & Marketable $^{1}$ & Total & & & \\
\hline \multirow{4}{*}{$\begin{array}{l}\text { Canoinhas } \\
\text { (Spring/2012) }\end{array}$} & BRS F63 (Camila) & $20.9 \mathrm{a}^{2}$ & $32.9 b$ & $63.9 \mathrm{a}$ & $90.4 a$ & $1.078 \mathrm{~b}$ \\
\hline & Agata & $16.1 \mathrm{ab}$ & $40.9 \mathrm{a}$ & $39.4 b$ & $57.9 b$ & $1.072 \mathrm{c}$ \\
\hline & Asterix & $11.8 \mathrm{~b}$ & $34.3 b$ & $34.6 b$ & $50.8 \mathrm{~b}$ & $1.088 \mathrm{a}$ \\
\hline & $\operatorname{LSD}(0.05)$ & 6.2 & 5.8 & 23.2 & 10.1 & 0.005 \\
\hline \multirow{4}{*}{$\begin{array}{l}\text { Brasília } \\
\text { (Winter/2012) }\end{array}$} & BRS F63 (Camila) & $29.0 \mathrm{a}$ & $38.2 \mathrm{a}$ & $74.8 \mathrm{a}$ & - & - \\
\hline & Agata & $22.3 \mathrm{a}$ & $36.4 \mathrm{a}$ & $62.1 \mathrm{a}$ & - & - \\
\hline & Asterix & $33.4 \mathrm{a}$ & $38.9 \mathrm{a}$ & $84.9 \mathrm{a}$ & - & - \\
\hline & $\operatorname{LSD}(0.05)$ & 22.3 & 22.9 & 19.6 & - & - \\
\hline \multirow{4}{*}{$\begin{array}{l}\text { Canoinhas } \\
\text { (Fall/2013) }\end{array}$} & BRS F63 (Camila) & $19.4 \mathrm{a}$ & $29.9 a$ & $64.9 \mathrm{a}$ & $120.5 \mathrm{a}$ & $1.073 \mathrm{~b}$ \\
\hline & Agata & $10.7 b$ & $23.1 \mathrm{~b}$ & $45.8 b$ & $101.1 \mathrm{a}$ & $1.073 b$ \\
\hline & Asterix & $14.3 \mathrm{ab}$ & $26.0 \mathrm{ab}$ & $55.1 \mathrm{ab}$ & $100.2 \mathrm{a}$ & $1.083 \mathrm{a}$ \\
\hline & $\operatorname{LSD}(0.05)$ & 6.0 & 6.4 & 23.1 & 25.4 & 0.005 \\
\hline \multirow{4}{*}{$\begin{array}{l}\text { Pelotas } \\
\text { (Fall/2013) }\end{array}$} & BRS F63 (Camila) & $22.0 \mathrm{a}$ & $23.6 \mathrm{a}$ & $93.5 \mathrm{a}$ & $109.6 \mathrm{a}$ & $1.075 \mathrm{~b}$ \\
\hline & Agata & $13.3 \mathrm{~b}$ & $17.5 \mathrm{a}$ & $77.4 \mathrm{a}$ & $72.3 b$ & $1.064 \mathrm{c}$ \\
\hline & Asterix & $16.7 \mathrm{~b}$ & $21.5 \mathrm{a}$ & $77.9 \mathrm{a}$ & $72.6 b$ & $1.079 \mathrm{a}$ \\
\hline & $\operatorname{LSD}(0.05)$ & 4.3 & 6.7 & 24.9 & 26.4 & 0.010 \\
\hline \multirow{4}{*}{$\begin{array}{l}\text { Canoinhas } \\
\text { (Spring/2013) }\end{array}$} & BRS F63 (Camila) & $23.8 \mathrm{a}$ & $50.6 \mathrm{a}$ & $33.9 \mathrm{a}$ & $107.9 \mathrm{a}$ & $1.073 \mathrm{a}$ \\
\hline & Agata & $9.0 \mathrm{~b}$ & $35.4 \mathrm{a}$ & $13.8 b$ & $67.9 b$ & $1.060 \mathrm{~b}$ \\
\hline & Asterix & $20.5 \mathrm{a}$ & $50.5 \mathrm{a}$ & $22.9 \mathrm{ab}$ & $92.3 \mathrm{ab}$ & $1.080 \mathrm{a}$ \\
\hline & $\operatorname{LSD}(0.05)$ & 9.2 & 16.7 & 12.9 & 29.1 & 0.009 \\
\hline \multirow{4}{*}{$\begin{array}{l}\text { Pelotas } \\
\text { (Spring/2013) }\end{array}$} & BRS F63 (Camila) & $15.3 \mathrm{a}$ & $20.3 \mathrm{a}$ & $74.9 \mathrm{a}$ & $64.7 \mathrm{a}$ & $1.073 \mathrm{a}$ \\
\hline & Agata & $5.4 b$ & $12.8 \mathrm{a}$ & $42.2 b$ & $35.6 b$ & $1.054 \mathrm{~b}$ \\
\hline & Asterix & $10.1 \mathrm{ab}$ & $20.1 \mathrm{a}$ & $49.8 b$ & $48.3 b$ & 1.081 \\
\hline & $\operatorname{LSD}(0.05)$ & 6.2 & 7.7 & 14.3 & 13.9 & 0.010 \\
\hline
\end{tabular}

Marketable tubers: tubers with transversal diameter larger than $45 \mathrm{~mm} .{ }^{2}$ Means followed by same letter in the column do not differ at the $5 \%$ level by the Tukey test; LSD: least significant difference.

only moderate resistance to late blight and to early blight, the control of both diseases can effectively be done with the use of fungicides.

The extreme resistance to PVY reduces the loss of seed quality allowing a higher number of generations of multiplication.

The susceptibility to physiological disorders when grown under higher temperature conditions makes 'BRS F63' (Camila) be preferentially recommended for planting in regions of the subtropical ecosystem, and only in the Winter season of the tropical ecosystem.

\section{MOLECULAR PROFILE}

The molecular profile of 'BRS
F63' (Camila) was obtained for the 24 microsatellite loci that compose the genetic identity kit developed for potatoes (Ghislain et al., 2009), following the protocol described by authors. BRS F63 (Camila) was characterized along with Agata the cultivar of yellow skin more widely cultivated in Brazil. The molecular profile of 'BRS F63' (Camila) is distinct from 'Agata' for loci STI001, STI0032, STI0033, STM0019, STM0037, and STM5114. The analysis of any of these loci differentiates the two cultivars. The alleles identified in these microsatellite loci in 'BRS F63' (Camila) are: STI001 (211/205/198/195 bp), STI0032 (142/137 bp), STI0033 (149/137/131 bp), STM0019 (208/131 bp), STM0037 (98/96/90 bp), and STM5114 (306/304 bp).

\section{CHEMICAL CHARACTERISTICS}

The total glycoalkaloid content of 'BRS F63' (Camila) tubers is within acceptable limits $\left(20 \mathrm{mg} 100 \mathrm{~g}^{-1} \mathrm{fresh}\right.$ weight). On average, the content was

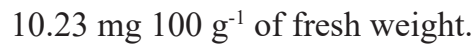

\section{PROTECTION, SEED AVAILABILITY, AND LICENSING}

The potato cultivar BRS F63 (Camila) is registered and protected by the Ministry of Agriculture, Livestock 
and Supply (MAPA) of Brazil since $18 / 08 / 2014$ under the number 32983 , and protection certificate from June 8 , 2015, under number 20150250.

Information about seeds can be obtained at Embrapa Products and Market, Office of Canoinhas, Rodovia BR 280, km 231, no 1151 Bairro Industrial 2, Caixa Postal 317, CEP 89460-000, Canoinhas-SC.

Phone:+55 (47) 3624-0127, 36240195 and 3624-2077. E-mail: ecan. spm@embrapa.br. http://spm.sede. embrapa.br/produtos/produtos/

\section{REFERENCES}

CLARK, MF; ADAMS, AN. 1977. Characteristics of the microplate method of enzyme linked immunosorbent assay for the detection of plant viruses. Journal of General Virology 34: 475-483.

BRIGNETI, G; GARCIA-MAS, J; BAULCOMBE, C. 1997. Molecular mapping of the potato virus Y resistance gene $R y_{\text {sto }}$ in potato. Theoretical and Applied Genetics 94: 198-203.

GHISLAIN, MG; NÚÑEZ, J; HERRERA, MR; PIGNATARO, J; GUZMAN, F; BONIERBALE, M; SPOONER, DM. 2009. Robust and highly informative microsatellitebased genetic identity kit for potato. Molecular Breeding 23: 377-388.
EHLENFELDT, MK; LOPEZ-PORTILLA, DF; BOE, AA; JOHANSEN, RH. 1990. Reducing sugar accumulation in progeny families of cold chipping potato clones. American Potato Journal 67: 83-91.

PEREIRA, AS; SILVA, GO; CASTRO, CM. 2016. Melhoramento de batata. In: NICK, C; BOREM,A (eds). Melhoramento de hortaliças. Viçosa: Editora UFV. p.128-157.

SCHAEFER, JT ; PEREIRA, AS ; BARROS, DR; GOMES, CB. 2017. Resistance of potato genotypes to Meloidogyne javanica. Revista Caatinga 2: 530-535.

THE POTATO ASSOCIATION OF AMERICA. 2016. Atlantic (Solanum tuberosum). Available at: http://potatoassociation.org/industry/ varieties/white-varieties/atlantic-solanumtuberosum. Accessed August 26, 2016. 